\title{
Креирање и вођење радионице за библиотекаре
}

\author{
Јелена Јовин \\ Библиотека Матице српске, Нови Сад \\ jovinj@bms.ns.ac.rs
}

\begin{abstract}
Сажетак
Рад се бави процесом настанка едукативне радионице, посматране као вид спровођења акредитованог програма у контексту сталног стручног усавршавања у библиотечко-информационој делатности у Србији (2014-2018).

У почетном делу успостављају се општи принципи и примери добре праксе из IFLA водича за стално стручно усавршавање и практичне смернице за ефикасно креирање радионица. У истраживачком делу примењен је модел функционалне флуентности и интерпретиран профил понашања водитеља, добијен на основу анонимне процене библиотекара (анализа 665 придева из 400 упитника). На профилу је опажено смањено изражавање негујућег начина понашања водитеља, предложене су корекције, али је и напоменуто питање поузданости прикупљених података. У закључку се препоручује системско увођење супервизије ради побољшања квалитета акредитованих програма.

Основни циљ чланка је да се истакну неопхдност сталног професионалног и персоналног усавршавања аутора/ водитеља, и последично, побољшање квалитета радионица, јер оне могу бити ефикасан, искуствен начин стицања знања, развијања социјализације и креативности библиотекара и, додатно, начин побољшања услуга и привлачења већег броја корисника у библиотеке.
\end{abstract}

Кључне речи: библиотекари, стално стручно усавршавање, едукативне радионице, радионичарски рад, процес креирања, принципи добре праксе, искуствено учење, функционална флуентност, евалуација

\section{Увод}

Стално стручно усавршавање доприноси побољшању квалитета постојећих или стварању нових, савремених услуга библиотека, а на личном плану, стицању нових знања, вештина и развоју личности библиотекара. Важност усавршавања препозната је у значајним документи-

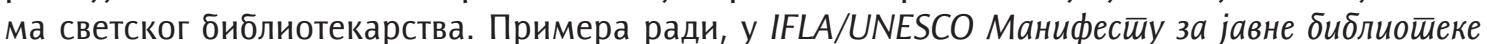
наводи се: „Библиотекар је активни посредник између корисника и извора. Да би се осигурале одговарајуће услуге, незаобилазно је стручно усавршавање и континуирано образовање библиотекара. ${ }^{\prime 1}$ Поред тога, IFLA Секција за стално стручно усавршавање и учење на радном месту (CPDWL)² дефинише опште принципе и примере добре праксе и даје свеобухватан преглед, полазећи од учесника, преко послодавца, библиотекарског друштва, предавача, до организатора обуке. ${ }^{3}$ У овом раду, пажња је усмерена на контекст сталног стручног усавршавања библиотекара у Србији и, прецизније, на учеснике и водитеља ${ }^{4}$ едукативне радионице

\footnotetext{
1 IFLA/UNESCO смернище за развој јавних библиошека (Београд: Народна библиотека Србије; Библиотека града Београда, 2005), 68.

2 Акроним од Continuing Professional Development and Workplace Learning. (прим. аут.)

3 Jana Varlejs, IFLA Guidelines for Continuing Professional Development: Principles and Best Practices (Hague: IFLA, 2016), preuzeto 10. 1 2019, https://www.ifla.org/files/assets/cpdwl/guidelines/ifla-guidelines-for-continuing-professional-development.pdf.

${ }^{4}$ У овом случају водитељ је истовремено и аутор радионице, мада то могу да буду и две различите особе.
} 


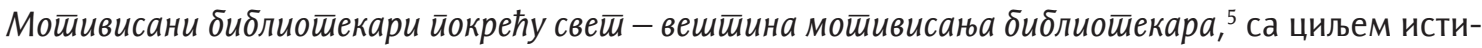
цања важности процеса усавршавања у креирању и вођењу радионице на основу евалуације и повратних информација учесника.

\section{Радионичарски начин рада}

Појам радионице, као главног предмета истраживања овог рада, означава структурирани метод рада у групи, са јасно дефинисаним током, према специфичном сценарију и конкретним циљевима, попут усвајања знања, понашања или вештина. Као савремени приступ у обучавању, одликује се активним учешћем присутних и интеракцијом са члановима групе, уз примену различитих облика рада ${ }^{6}$ као што су: презентација, асоцијације (енг. brainstorming), искуствене и креативне вежбе изводљиве појединачно или у мањој групи, дебата, играње улога, вођена фантазија итд. Правила рада дефинисана на самом почетку дају јој озбиљност и оквир за настанак повољне радне атмосфере, а односе се на поштовање правила комуникације, права на различитост, приватност итд. Водитељ има задатак да усмерава групу кроз процес учења до постизања циља, да прати активност и коригује темпо рада, удаљавање од теме, (не) истицање појединаца, сумира и даје закључке. Дакле, у односу на класичан ех cathedra начин образовног рада, радионица доноси интеракцију и динамику и, поред стицања знања, доприноси социјализацији учесника и развоју креативности.

Радионичарски рад може бити један од начина спровођења акредитованог програма ${ }^{8}$ у оквиру сталног стручног усавршавања у библиотечко-информационој делатности у Србији. Прописани ток акредитације програма подразумева позитивну оцену рецензента, пријављивање на конкурс и позитивну оцену надлежне Комисије. У периоду 2014-2018. реализоване су три акредитоване едукативне радионице посвећене појединим психолошким аспектима библиотечке струке: асертивним понашањем у раду са корисницима, конфликтним ситуацијама на радном месту ${ }^{9}$ и унутрашњом мотивацијом за рад. Искуство стечено током петогодишњег рада са библиотекарима и књижничарима широм Србије заправо је темељ овог рада.

Радионице као метод рада заступљене су у библиотекама. Могу се користити не само у циљу едукације библиотекара, наставника или ученика, ${ }^{10}$ већ и привлачења различитих група корисника. На пример, промовисање читања, обука за претраживање електронског каталога, упознавање са принципима библиотерапије, одређеним књижевним делом, историјском личношћу, догађајем или правцем из сликарства, само су неке од идеја које могу бити значајне за специфичне групе корисника и могу се реализовати кроз радионичарски рад у сарадњи са предшколским установама, школама, музејима, галеријама, позориштима и др. Због значајног потенцијала који могу имати у библиотекарству, у наставку су понуђене смернице за креирање са примерима из праксе.

\footnotetext{
5 Акредитована је у оквиру програма сталног стручног усавршавања у библиотечко-информационој делатности у Србији 20172018. године. Одржано је 26 радионица у 21 библиотеци са 484 библиотекара и књижничара, који су је анонимно проценили просечном оценом 4,65

${ }^{6}$ Obuka za radioničarski rad, akreditovan program (skripta) (Novi Sad: Tim centar, 2014), 2.

7 Техника радионичарског рада која има за циљ да се, уз водитељево усмеравање и подстицање маште, ствара искуство потребно ради разраде нових садржаја.

8 Члан 6. „Правилник о сталном стручном усавршавању у библиотечко-информационој делатности”, Службени іласник РС број 18 (2013), преузето 3. 3. 2019, https://www.nb.rs/view_file.php?file_id=3495.

9 Едукативна радионица Уйрављање конфликиима у библиошекама - у сусреши сииварању ефикасної раgної окружења акредитована је 2015-2016. године. Одржано је укупно 35 радионица са 679 библиотекара и књижничара, и постигнута је просечна оцена 4,6. Jelena Jovin, "Managing Conflicts in Serbian Libraries" (paper presented at: IFLA WLIC 2017, Wroclav, Poland, Libraries. Solidarity. Society, in Session 112- Poster Sessions), preuzeto 9. 3. 2019, http://library.ifla.org/1864/. Статистички подаци о реализацији друге две радионице наведени су у фуснотама 5 и 18.

10 Силвија Богдановић, „Креативне радионице у школским библиотекама - водич ка савременој школи”, у Креатиивне раgионице у
} школској библиоиеци. Књ. 1, уредник Александра Вранеш (Београд: Филолошки факултет Универзитета, 2011 ), 121. 


\section{Процес и фазе креирања радионице}

Радионица пролази кроз различите фазе током процеса настанка. Према општем закључку у IFLA воgичу за стиално стиручно усавршавање, наглашавају се стручност водитеља и фазе развоја једног успешног програма стручног усавршавања: „Најбоља пракса захтева стручност реализатора у дизајнирању наставе, презентацији, спровођењу и евалуацији програма континуираног професионалног развоја. ${ }^{\prime 11}$

Детаљнији опис карактеристика наведених фаза изведен је према редоследу у ADDIE Mogeлу. ${ }^{12}$ Ток процеса стварања радионице започиње анализом потреба будућих учесника, а наставља се одређивањем теме, дизајнирањем начина на који ће тема бити обрађена и остварени циљеви, затим развојем садржаја, метода рада и пропратног материјала, да би се завршио реализацијом и евалуацијом радионице. На основу повратних информација, могуће су измене и допуне у структури и/или методама рада са циљем побољшања ефективности.

Први корак ка избору предмета истраживања радионице је посматрање прилика у библиотеци, испитивање библиотекара путем анкета, фокус група или индивидуалних интервјуа. Након избора теме и проучавања релевантне области, потребно је изабрати адекватан теоријски оквир и технике рада за ефектно приказивање најважнијих појмова.

Избор одговарајућих техника је најзахтевнији и, истовремено, најкреативнији део процеса. Притом би требало имати у виду неколико чињеница које могу утицати на ефективност рада. Прво, водити рачуна о количини информација којима се излажу учесници, јер је капацитет краткотрајне меморије ограничен на 7 плус/минус 2 елемента. ${ }^{13}$ У складу са тим, водитељ би требало јасно и гласно да презентује садржај и да визуелно истакне и сумира најважније идеје. Друго, због постојања индивидуалних разлика у стиловима учења, битно је одабрати разноврсне технике како би се укључили сви начини усвајања знања, од теоријских објашњења, примене теорије, практичног искуства, до стварања идеја. Водитељ има задатак да кроз активност изазове искуство везано за циљ и тему и да води групу кроз процес трансформације искуства у учење. ${ }^{14}$ Треће, најбољи ефекти у учењу се постижу утврђеним редоследом метода рада: презентација, примена и повратна информација. Прво се излажу и објашњавају теоријски концепти, затим се примењују кроз активност и, на крају, размењују повратне информације између водитеља и учесника. У фази структурирања радионице важно је и правилно ускладити временску смену теоријског и практичног дела. Боб Пајк ${ }^{15}$ истиче правило 90/20/8 и објашњава: „Ниједан модул не траје дуже од 90 мин., ритам мењамо на сваких 20 мин., и покушавамо да укључимо људе у садржај сваких 8 мин“. ${ }^{16}$ Уколико се водитељ не придржава овог правила, вероватно је да ће евалуација садржати придеве као што су: дуго, досадно, пасивно и сл.

\footnotetext{
11 Varlejs, IFLA Guidelines for Continuing Professional Development..., 46. (прев. аут.)

12 Акроним од Analysis, Design, Development, Implementation, and Evaluation. (прим. аут.) Модел је заснован на психолошким сазнањима о подучавању, развоју и вођењу радионица. Jerilyn Veldof, Creating the One-Shot Library Workshop: A Step-by-Step Guide (Chicago: American Library Association, 2006), 3.

13 Џорџ А. Милер, когнитивни психолог на Универзитету у Принстону је 1956. године експериментално показао да просечан човек може обратити пажњу само на ограничен број елемената - између 5 и 9. Број елемената са којима је могуће истовремено оперисати може бити већи уколико су они груписани у смисаоне јединице. На пример, када искусни библиотекар каталогизатор опази реч UNIMARC знаће да се ради о универзалном формату за библиографске податке и обрадиће га као једну смисаону јединицу. Почетнику који не зна смисао дате скраћенице биће теже да памти 7 елемената (појединачна слова). Александар Костић, Коїнишиивна йсихолоїија (Београд: Завод за уџбенике и наставна средства, 2006), 115; Veldof, Creating the One-Shot Library Workshop..., 93-94.

14 Према Mogeлу искусиввеної учења оgраслих Дејвида Колба (David A. Kolb, 1939-), учење је кружни процес који у радионичарском раду почиње конкретним искуством током главне активности, наставља се рефлексијом (описивањем и разумевањем доживљеног и стицањем увида), затим се искуство генерализује - повезује са реалним животом и стеченим искуствима, да би се на крају, научено искуство могло интегрисати и примењивати у реалном животу планирањем конкретних акција. - Danijela Živančević, Asertivni trening u humanistički usmerenim tretmanima: kurs za obuku trenera asertivnosti: skripta (Novi Sad: Psihopolis institut, 2014).

15 Robert William Pike (1947-), оснивач компаније The Bob Pike Group, познате по обучавању предавача. Аутор је популарног приручника The Creative Training Techniques Handbook.

${ }^{16}$ Veldof, Creating the One-Shot Library Workshop..., 89.
} 
Зарад илустрације техника у радионичарском раду, требало би навести неколико најзапаженијих искуствених вежби из досадашње праксе. По ефективности се издвојила пројективна техника која се састоји у бирању фотографије која најбоље представља конфликт са радног места ${ }^{17}$ јер је нудила јасан увид у карактеристике конфликтне ситуације. Затим, групно вежбање вештине слушања и парафразирања јасно је указивало на постојање потешкоћа и неправилности у преношењу туђег говора и укључивало је све учеснике у процес на тај начин што су, поред активних, и пасивни учесници имали улогу посматрача и процењивача. Играње улога (енг. role play) је техника којом се кроз директно искуство увежбава жељено понашање. Примењена у радионици асертивног понашања, ${ }^{18}$ омогућила је вежбање презентованих принципа у конкретним ситуацијама из библиотечког окружења. Врло успешан, креативан и изазован, показао се задатак који је подстицао стварање идеја за реализацију будућег пројекта у библиотеци. Подељени у групе, библиотекари су анализирали и расправљали о потребним активностима и ресурсима за осмишљавање манифестација у њиховој библиотеци на теме: како су писали, како су се облачили или које приче су волели наши преци, како је у прошлости изгледао наш град итд. Дакле, карактеристике добро осмишљених вежби су: да укључују све учеснике, позивају их да мисле и примене научено, подстичу сарадњу и да буду занимљиве.

Успех радионице у великој мери зависи од обучености, вештина презентовања, фацилитације и успостављања коректног односа водитеља са групом. Током фазе реализације, његов задатак је не само да групи омогући учење путем искуства, већ и да путем успешне комуникације створи атмосферу подршке и поверења. Приручници за обуку водитеља истичу различите особине и вештине пожељне за рад са људима, на пример: „Добар водитељ радионице испољава демократичност, висок степен толеранције на фрустрацију, флексибилност, контакт са собом". ${ }^{19}$ С обзиром на то да је споменуто постојање флексибилности и усмерености на сваког члана групе важно (и захтевно за водитеља), илустроваћемо га кроз метафору у причи Абдула Баха „Васпитач и вртлар“: „Рад васпитача сличан је раду вртлара, који негује различите биљке. Једна биљка воли блистав Сунчев сјај, друга хладне сенке; једна воли обалу потока, друга сушан планински врх. Једна најбоље успева на пешчаном тлу, друга на масној иловачи. Свакој се мора пружити нега која одговара њеној врсти; у противном, биљка не достиже савршенство ${ }^{20}$

Евалуација је последња фаза у процесу и представља поступак прикупљања информација на рашомонски ${ }^{21}$ начин, у циљу постизања веће објективности. Она даје увид у начињене грешке и представља водич за увођење промена. Са једне стране, врши је водитељ, а са друге учесници путем процене на анонимном упитнику. С обзиром на то да може бити извор драгоцених информација, упитник би требало да садржи питања која провоцирају одговоре релевантне за анализу. У досадашњој пракси, за квантитативно мерење ставова коришћена је Ликертова скала 1-5, а за квалитативно, описивање помоћу 3 придева следећих аспеката радионице: општи утисак, теорија, вежбе, групни рад и атмосфера и водитељ. На крају, учесници су могли изразити критику и предложити тему за наредну радионицу.

Суштина квалитетно дизајниране и вођене радионице је у правилном балансу и прилагођеном садржају који може задовољити основне људске потребе за структуром, препознавањем и

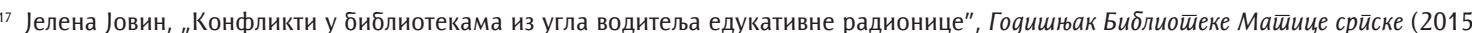
[шт. 2016]): 235, преузето 12. 2. 2019, http://digital.bms.rs/ebiblioteka/pageFlip/reader/index.php?type=numerated\&id=6107\&m= 2\#page/1/mode/2up.

18 Едукативна радионица Асерйивно йонашање у библиошекама акредитована је2014. године. Реализовано је 13 радионица у којима је учествовало 193 библиотекара и књижничара.

${ }^{19}$ Obuka za radioničarski rad, 10

${ }^{20}$ Nosrat Peseškijan, Istočnjačke priče u psihoterapiji: s primerima za odgoj i samopomoć (Beograd: Nolit, 1991), 67.

21 Више различитих мишљења учесника о истом догађају. Рашомон је јапански филм у режији Акире Куросаве који се бави пита-
} њем постојања истине (објективност), јер сваки сведок има своју субјективну верзију истог догађаја (прим. аут.). 
стимулусима. ${ }^{22}$ Радионица би требало да се бави актуелном темом, да има адекватну структуру, јасну логику и смену различитих активности. Поред тога, у процесу учења важни су емотивни и социјални фактори, динамика и мотивација, занимљивост и енергија, едукативна вредност и могућност примене у пракси. ${ }^{23}$ Искуство извођења и уважавање повратних информација учесника усмеравају измене и воде ка идеалном. На тај начин и аутор може да учи и усавршава се на основу искуства.

\section{Вештине успешног водитеља радионице}

Како се међу општим смерницама IFLA воgича наглашава, за добру праксу у стручном усавршавању неопходни су „инструктори који имају адекватне способности за извођење наставе, стручност у релевантној области и сензибилитет према ученицима“. ${ }^{24}$ То би значило да за су за ефикасно вођење радионице и рад са групом, поред релевантног знања, потребни висок степен емоционалне и социјалне интелигенције.

За илустрацију практичних смерница за успешно вођење радионице, наведени су примери Џерилин Велдоф, ${ }^{25}$ библиотекара на Универзитету у Минесоти. Карактеристике успешног водитеља, према њеном мишљењу, су: да говори јасно и адекватном брзином, избегава поштапалице, уме да мења тон, висину и ритам говора да би истакао битне тачке; уме да одржи пажњу учесника; поставља јасна питања и даје адекватне одговоре, као и јасна, логична упутства. ${ }^{26}$ Поред тога, она истиче да би водитељ требало да привлачи пажњу учесника кретањем по простору, да наглашава битне информације променом висине гласа, прављењем паузе или користећи визуелни показивач. Социјалне вештине водитеља наглашава у виду способности да ствара топлу, пријатељску и опуштену атмосферу, ради са ентузијазмом, реагује на знаке неразумевања код учесника, подстиче активност и дискусију, одржава добар контакт очима и поклања пажњу учесницима, поткрепљује сарадњу насупрот доминације.

За анализу емоционалног и социјалног функционисања водитеља, примењен је концепт функционалне флуентности. ${ }^{27}$ Аутор концепта, Сузан Темпл, ${ }^{28}$ дефинише га као вештину ефикасног функционисања у интерперсоналним односима, која се манифестује кроз флексибилно и уравнотежено испољавање различитих начина понашања. ${ }^{29}$ Модел има за циљ да укаже на важност рада на себи, како би се водитељ чешће понашао на спонтан, флексибилан и ефикасан начин и тиме задобио наклоност и пажњу учесника, разумео њихове потешкоће, пружио им сигуран оквир и подучавао са ентузијазмом. ${ }^{30}$ У моделу је описано девет начина понашања (шематски приказ 1.), од којих пет има позитивну функцију: структурирајући, негујући, рационалан, сарадљив и спонтан начин, ${ }^{31}$ а четири негативну: доминирајући, сладуњав, ${ }^{32}$ повлађујући/бунтован и незрео начин. ${ }^{33}$

\footnotetext{
22 Trudy Newton, "The Supervision Triangle: an Integrating Model", Transactional Analysis Journal Vol. 42, no. 2 (April 2012): 104, doi. org/10.1177/036215371204200203.

23 Анализом придева којима су учесници описивали општи утисак о радионици на тему мотивације, показало се да су од укупно 798 придева највећу учесталост јављања имали следећи придеви: занимљиво (123), корисно (74) и йоуино (50).

${ }^{24}$ Varlejs, IFLA Guidelines for Continuing Professional Development..., 42. (прев. аут.)

25 Бави се дизајнирањем и вођењем радионица. - Jerilyn Veldof, https://www.linkedin.com/in/jveldof

${ }^{26}$ Veldof, Creating the One-Shot Library Workshop...,146.

27 Трансакционо-аналитички концепт примењен у области образовања.

28 За концепт функционалне флуентности Сузан Темпл је добила Меморијалну награду Ерик Берн, коју додељује Међународно удружење трансакционих аналитичара (ITAA) 2014. године.

29 Susannah Temple, “Update on the Functional Fluency Model in Education”, Transactional Analysis Journal Vol. 34, no. 3 (July 2004):197.

30 Susannah Temple, "Functional Fluency for Educational Transactional Analysts", Transactional Analysis Journal Vol. 29, no. 3 (1999): 164-174. doi: 10.1177/036215379902900302: 164

31 Eng. Structuring, Nurturing, Accounting, Cooperative, Spontaneous Mode. (прев. аут.)

32 Карактеристика овог начина је давање позитивних, али неискрених строукова (јединица препознавања) - сладуњаво препознавање (eng. marshmallowing).-In Stjuart i Ven Džoins, Savremena transakciona analiza (Novi Sad: Psihopolis institut, 2011), 466.

33 Eng. Dominating, Marshmallowing, Compliant/Resistant, Immature mode. (прев. аут.)
} 


\begin{tabular}{|c|c|}
\hline $\begin{array}{l}\text { Негативна контрола } \\
\text { Доминирајући начин }\end{array}$ & $\begin{array}{l}\text { Негативна нега } \\
\text { Сладуњав начин }\end{array}$ \\
\hline $\begin{array}{c}\text { Позитивна контрола } \\
\text { Структурирајући начин }\end{array}$ & $\begin{array}{l}\text { Позитивна нега } \\
\text { Негујући начин }\end{array}$ \\
\hline \multicolumn{2}{|c|}{$\begin{array}{l}\text { Обрада информација } \\
\text { Рационалан начин }\end{array}$} \\
\hline $\begin{array}{c}\text { Позитивно социјализован селф } \\
\text { Сарадљив начин }\end{array}$ & $\begin{array}{c}\text { Позитиван природан селф } \\
\text { Спонтани начин }\end{array}$ \\
\hline $\begin{array}{l}\text { Негативно социјализован селф } \\
\text { Повлађујући/Бунтован начин }\end{array}$ & $\begin{array}{c}\text { Негативан природан селф } \\
\text { Незрео начин }\end{array}$ \\
\hline
\end{tabular}

\section{Шематски приказ 1. Модел функционалне флуентности}

Водитељ са усвојеном вештином функционалне флуентности је свестан личних и спољашњих доживљаја (рационалан начин), саосећа са учесницима (негујући начин), даје упутства и поставља границе на јасан, коректан начин (структурирајући начин), отворен је и пријатељски настројен (сарадљив начин), креативан је и слободно изражава жеље и емоције (спонтан начин). Са друге стране, претпоставља се да такав водитељ неће наређивати, нити константно тражити другима грешке (доминирајући начин), претерано попуштати и радити уместо других (сладуњав начин). Такође, неће слепо следити мишљење других или имати потребу да се стално супротставља (повлађујући/бунтован начин). И додатно, мало је вероватно да ће се понашати на детињаст, егоцентричан или импулсиван начин (незрео начин).

Описани начини понашања послужиће као основа за анализу понашања водитеља, у циљу добијања што објективније слике, уочавања слабих тачака и њиховог кориговања у будућем раду и, самим тим, побољшања ефективности радионице.

\section{Евалуација понашања водитеља радионице}

Поступак евалуације понашања водитеља на основу анонимне процене 35 учесника спроведен је у периоду 2017-2018. Прикупљено је укупно 400 упитника и, применом технике анализе садржаја на 665 придева ${ }^{36}$ који се односе на рад водитеља, сваки придев је разврстан у једну од девет категорија, тако да смислено одговара опису једног од девет начина понашања из модела функционалне флуентности.

Профил понашања водитеља добијен на основу учесталости јављања придева у дефинисаним категоријама представљен је на графичком приказу 1. Према постигнутим резултатима, учесници су проценили да је водитељ испољавао пет позитивних начина понашања. Приближно једнака висина три ступца указује на то да је водитељ испољавао следећа три на-

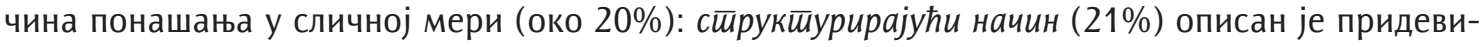
ма: разумљив, гласан, елоквентан, организован, сигуран, темељан, предан, озбиљан, упечатљив; рационалан начин (21\%) придевима: професионалан, образован, барата чињеницама,

\footnotetext{
34 Ја (сопство), свесни део личности, односно субјект који опажа, осећа, мисли, планира, процењује и контролише понашање.

35 Анонимношћу се желе постићи већа објективност и валидност у мерењу, али се теже могу избећи утицаји механизма йројекиије (несвестан процес по којем, у овом случају, личне особине учесника могу бити приписане водитељу) или gавања социјално йожељних оgїовора (учесник одговара оно што мисли да се од њега тражи, или што ће га представити у бољем светлу, уместо онога што стварно мисли). - Stanislav Fajgelj, Bora Kuzmanović i Borislav Đukanović, Metodologija socijalnih istraživanja: (skripta) (Novi Sad: Filozofski fakultet, 2003), 184.

36 Учесници су имали задатак да напишу три придева који најбоље описују водитеља радионице. Поред квалитативне, дали су и процену заокруживањем броја на скали $1-5$
} 
објективан, продуктиван, преноси знање, фокусиран, паметан, сталожен, свестран; и сараgљив начин (22\%) описан је придевима: пријатан, љубазан, коректан, комуникативан, кооперативан, приступачан, непосредан, толерантан, флексибилан, смирен, умилан, допадљив. Највећу учесталост постигао је сйоншиан начин понашања водитеља (33\%), и учесници су га описали помоћу придева: занимљив, опуштен, духовит, радознао, динамичан, иновативан, мотивишући, креативан, маштовит, шармантан. У најмањој мери опажен је неїујћи начин понашања (само 3\%) и описан је речима и придевима попут: предусретљив, добронамеран, пажљив, зна да слуша и на прави начин одговори, помажући, добар, топао, емпатичан, ослушкује људе и реагује на конкретне учеснике.

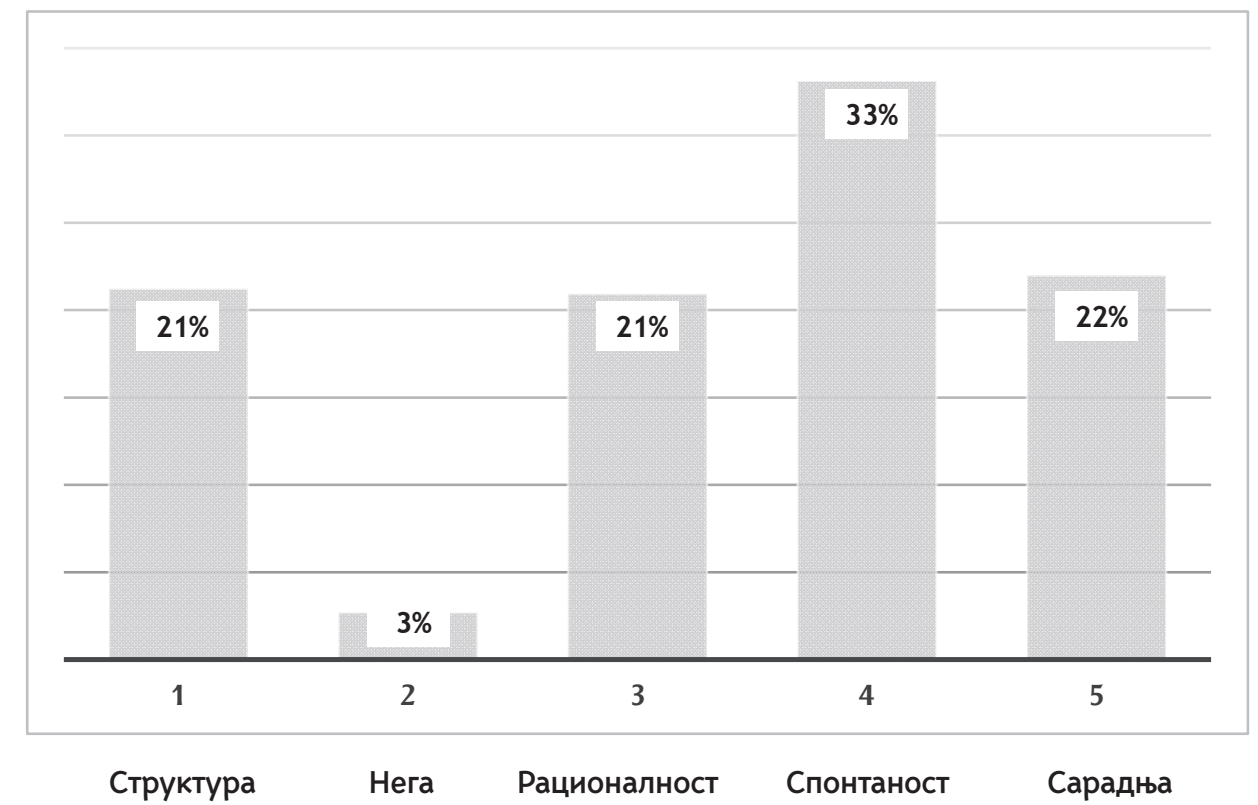

Графички приказ 1. Профил понашања водитеља

Према резултатима може се закључити да је водитељ током радионице најчешће испољавао позитивне начине понашања из модела функционалне флуентности. Другим речима, био је опуштен, отворен, спонтан, сарадљив и ентузијастичан и на тај начин допринео је стварању пријатне атмосфере и мотивисању учесника. Запажене су његове стручне карактеристике, припремљеност и едукованост за рад, а у прилог чињеници да нису опажена негативна понашања, иде и релативно висока оцена постигнута на Ликертовој скали (4,65 од максималних 5). Податак о слабо израженој негујућој компоненти у понашању указује на потребу за чешћом разменом повратних информација са учесницима, више охрабривања и упућивања похвала, као и праћење понашања и конкретних потреба појединаца. Истовремено, прихваћен као недостатак, овај резултат може бити смерница за корекције у будућем раду.

За водитеља свако искуство извођења радионице може бити извор усавршавања. Према Сузан Темпл, водитељ може радом на себи ${ }^{37}$ постати свеснији негативних начина понашања, предрасуда, заблуда и њихових штетних утицаја у раду. Истовремено, може постати свестан могућности да их замени позитивним начинима понашања и тиме отвори пут ка испољавању објективности, спонтаности и блискости. На тај начин његов рад постаје ефектнији, долазе

\footnotetext{
37 Она предлаже рад у едукативној групи која нуди подршку, сарадњу, примере из праксе и дискусију.
} 
до изражаја таленат, способности и стручност. Зато су континуирано стицање знања и рад на себи важни, а посебно за водитеље који због природе посла примарно користе и истичу своје знање и вештине. У том смислу, Сузан Темпл закључује: „На крају, едукатори користе себе као примаран алат у раду, и зато су за њих лични и професионални развој синоними“. ${ }^{38}$

\section{Закључак}

Вратимо се на контекст и сврху програма сталног стручног усавршавања у библиотечко-информационој делатности у Србији. Након извршене анализе повратних информација учесника из анонимног упитника, намеће се неколико питања везаних за евалуацију и квалитет програма: Да ли су потребни јединствени критеријуми за процену квалитета програма сталног стручног усавршавања? Да ли је евалуација на основу процене учесника довољна за постизање њиховог задовољавајућег квалитета? Да ли је потребна додатна, екстерна евалуација супервизора?

За побољшање квалитета програма стручног усавршавања и њихову евалуацију потребно је пратити решења, трендове, примере добре праксе у библиотекарству других земаља ${ }^{39}$ или сличним областима деловања нпр. образовни систем ${ }^{40}$ и прилагођавати их потребама библиотекара. Тим активностима требало би да се бави тело на вишем нивоу, које би надзирало програме и рад предавача, или анализирало потребе библиотекара и у складу са њима бирало програме. ${ }^{41}$ За сада, такав орган не постоји (осим Комисије за акредитацију програма сталног стручног усавршавања).

Из перспективе аутора акредитованог програма, зарад побољшања његове ефективности, постоји потреба за сталним професионалним и личним усавршавањем. У недостатку детаљног законског оквира, ${ }^{42}$ аутор анализиране радионице је препуштен личној савести, посвећености и мотивацији за постављање критеријума квалитета у току креирања и вођења радионице, као и жељи за додатним образовањем и радом на себи како би успешно кориговао недостатке. И поред високих оцена у анкети, требало би узети у обзир факторе који утичу на њихову валидност $^{43}$ (неискреност, давање социјално пожељних одговора, пројекција). Из наведених разлога, квалитет радионице би се могао додатно проценити поступком супервизије. ${ }^{44}$

Коначно, рад на побољшању квалитета акредитованих програма може бити користан и подстицајан за све актере на различитим нивоима система стручног усавршавања, од супервизора, преко аутора, до учесника програма. У крајњој инстанци, сви они заправо имају конвергентне циљеве попут стицања нових компетенција, побољшања квалитета услуга и више задовољних корисника.

38 Temple, "Update on the Functional Fluency Model in Education": 204. (прев. аут.)

39 IFLA воgии за сйално сиируино усавршавање: ириниийи и иримери gобре ираксе нуди детаљан преглед свих аспеката сталног стручног усавршавања.

40 Пример много разрађенијег система стручног усавршавања може бити: Правилник о сталном стручном усавршавању и напредовању у звања наставника, васпитача и стручних сарадника", Службени іласник PC број 62 (2016), преузето 3. 3. 2019, http://www. mpn.gov.rs/wp-content/uploads/2015/09/PRAVILNIK-STRUCNO-USAVRSAVANJE-24.08.2017.pdf.

41 Детаљну анализу статистичких података и процену квалитета одржаних акредитованих програма у периоду 2014-2017. извршило је Одељење за истраживање и развој библиотечко-информационог система - Матично одељење Народне библиотеке Србије. Резултати анкете указују на конкретне области рада библиотекара за које постоји потреба за усавршавањем. - Добрила Бегенишић, "Акредитовани програми сталног стручног усавршавања у библиотечко-информационој делатности у Србији (2014-2017)", Гласник Нароgне библиошеке Србије Год. 17, бр. 20 (2018): 123-144, преузето 8. 3. 2019, https://www.nb.rs/view_file.php?file_id=5992.

42 „Правилник о сталном стручном усавршавању у библиотечко-информационој делатности“ не бави се питањем квалитета и евалуацијом програма.

${ }_{43}$ Валидност или ваљаност у психометрији је карактеристика теста или скале која показује да ли он мери оно што треба да мери, и у ком степену.

44 Трансакциони аналитичари Њутон и Напер сматрају да је супервизија најважнији део сталног стручног усавршавања на личном и професионалном плану, и посматрају га као процес заједничког учења у којем обе стране (супервизирани и супервизор) имају користи, јер развијају капацитет за самосталан рад. - Trudy Newton and Rosemary Napper,"The Bigger Picture: Supervision as an Educational Framework for All Fields", Transactional Analysis Journal Vol.37, no.2 (April 2007):150,doi.org/10.1177/036215370703700208. 


\section{Литература и извори:}

1. Begenišić, Dobrila. „Akreditovani programi stalnog stručnog usavršavanja u bibliotečko-informacionoj delatnosti u Srbiji (2014-2017)". Glasnik Narodne biblioteke Srbije God. 17, br. 20 (2018): 123-144. Preuzeto 8. 3. 2019. https://www.nb.rs/view_file.php?file_id=5992.

2. Bogdanović, Silvija. "Kreativne radionice u školskim bibliotekama - vodič ka savremenoj školi”. U Kreativne radionice u školskoj biblioteci. Knj. 1, urednik Aleksandra Vraneš, 119-129. Beograd: Filološki fakultet Univerziteta, 2011.

3. Fajgelj, Stanislav, Bora Kuzmanović i Borislav Đukanović. Metodologija socijalnih istraživanja: (skripta). Novi Sad: Filozofski fakultet, 2003.

4. IFLA/UNESCO smernice za razvoj javnih biblioteka. Beograd: Narodna biblioteka Srbije; Biblioteka grada Beograda, 2005.

5. Jovin, Jelena. "Managing Conflicts in Serbian Libraries". Paper presented at: IFLA WLIC 2017, Wroclav, Poland. Libraries. Solidarity. Society. in Session 112- Poster Sessions. Preuzeto 9. 3. 2019. http://library.ifla.org/1864/.

6. Jovin, Jelena. „Konflikti u bibliotekama iz ugla voditelja edukativne radionice”. Godišnjak Biblioteke Matice srpske (2015 [št. 2016]): 232-239. Preuzeto 12. 2. 2019. http://digital.bms.rs/ebiblioteka/ pageFlip $/$ reader $/$ index.php?type $=$ numerated $\& i d=6107 \& \mathrm{~m}=2 \#$ page $/ 1 / \mathrm{mode} / 2$ up .

7. Kostić, Aleksandar. Kognitivna psihologija. Beograd: Zavod za udžbenike i nastavna sredstva, 2006.

8. Newton, Trudi. "The Supervision Triangle: an Integrating Model". Transactional Analysis Journal Vol. 42, no. 2 (April 2012): 103-109. doi.org/10.1177/036215371204200203.

9. Newton, Trudi and Rosemary Napper. "The Bigger Picture: Supervision as an Educational Framework for All Fields". Transactional Analysis Journal Vol. 37, no. 2 ( April 2007): 150-158. doi. org/10.1177/036215370703700208.

10. Obuka za radioničarski rad. Akreditovan program (skripta). Novi Sad: Tim centar, 2014.

11. Peseškijan, Nosrat. Istočnjačke priče u psihoterapiji: s primerima za odgoj i samopomoć. Beograd: Nolit, 1991.

12. „Pravilnik o stalnom stručnom usavršavanju i napredovanju u zvanja nastavnika, vaspitača i stručnih saradnika". Službeni glasnik RS broj 62 (2016). Preuzeto 3. 3. 2019. http://www.mpn.gov.rs/wp-content/ uploads/2015/09/PRAVILNIK-STRUCNO-USAVRSAVANJE-24.08.2017.pdf.

13. „Pravilnik o stalnom stručnom usavršavanju u bibliotečko-informacionoj delatnosti”. Službeni glasnik RS broj 18 (2013). Preuzeto 3. 3. 2019. https://www.nb.rs/view_file.php?file_id=3495.

14. Stjuart, In i Ven Džoins. Savremena transakciona analiza. Novi Sad: Psihopolis institut, 2011.

15. Temple, Susannah. "Functional Fluency for Educational Transactional Analysts". Transactional Analysis Journal Vol. 29, no. 3 (1999): 164-174. doi: 10.1177/036215379902900302.

16. Temple, Susannah. "Update on the Functional Fluency Model in Education". Transactional Analysis Journal Vol. 34, no. 3 (July 2004): 197-204.

17. Varlejs, Jana. IFLA Guidelines for Continuing Professional Development: Principles and Best Practices. Hague: IFLA, 2016. Preuzeto 10. 1. 2019. https://www.ifla.org/files/assets/cpdwl/guidelines/ifla-guidelinesfor-continuing-professional-development.pdf.

18. Veldof, Jerilyn. Creating the One-Shot Library Workshop: A Step-by-Step Guide. Chicago: American Library Association, 2006.

19. Živančević, Danijela. Asertivni trening u humanistički usmerenim tretmanima: kurs za obuku trenera asertivnosti: skripta. Novi Sad: Psihopolis institut, 2014. 


\title{
Creating and Conducting a Workshop for Librarians
}

\begin{abstract}
Summary
This paper deals with the process of creating an educational workshop, as a way of implementing an accredited program within the context of continuing professional development in Serbian librarianship. The analysis is based on three different psychological workshops created and conducted in different libraries, in the period 2014-2018.

In the initial part of the paper, general principles and the best practice examples from the IFLA Guidelines for Continuing Professional Development are outlined, as well as practical guidelines for the efficient creation of workshops. In the research part, the paper deals with the case study analysis of functional fluency in the behavior of the person who conducted the workshops. The profile interpretation is based on the anonymous evaluation carried out after the workshop Motivated Librarians Can Move the World - Motivational Skills for Librarians (2017-2018). In the first phase, following the applied model of functional fluency, the main categories are defined. The analysis included 665 adjectives (collected from 400 questionnaires), used by librarians to describe the behaviour of the person who conducted the workshop. The profile shows that she behaved in a positive way, mainly spontaneously, enthusiastically, and consequently, created a positive working atmosphere which motivated librarians. Also, her professionalism, readiness, and expertise were frequently observed. The low score in the nurturing mode could be a guideline for giving/seeking more feedback, showing empathy, support, praisal, or sensitivity for participants needs. Additionally, it was pointed out that factors like dishonesty, giving socially desirable answers, or projection, could affect the validity of data from the questionnaire. Finally, the supervision is suggested as a method for the programme quality improvement.

The main aim of the paper is to emphasize the necessity of continuing professional and personal development of the authors/persons who conduct workshops, which will consequently improve the quality of their workshops. Workshops could be an efficient method for experience-based learning, developing the social skills and creativity of librarians, furthermore, a method for improving services and attracting more users to the library.
\end{abstract}

Keywords: librarians, continuing professional development, educational workshops, workshop activity, creation process, best practice principles, experiential learning, functional fluency, evaluation 


\section{(c) $\mathbb{\oplus \Theta \Theta}$}

Креирање и вођење радионице за библиотекаре bу Јелена Јовин is licensed under a Creative Commons Attribution-NonCommercial-NoDerivatives 4.0 International License. 